\title{
Special Anti-Robbery Squad operations and restructuring in Nigeria: Semiotics of the \#EndSARS protests
}

\author{
Nnennaya Uchendu Ola \\ Gregory University, Uturu, Abia State, \\ Department of Theatre \& Media Studies.
}

\begin{abstract}
:
"End Special Anti-Robbery Squad" (\#EndSARS) protests represent symptoms of systemic issues in Nigeria. Those issues range from ideological differences of the various ethnic nationalities to the constitutional and structural imbalance in the political and economic equation. This paper attempts to put in perspective the implications of the over-centralisation of both political and economic powers. To do this, this research examines the events leading up to the \#EndSARS protests, as well as the various signs and symbols emanating from the \#EndSARS movement. Semiotics Theory is employed as conceptual framework and methodology to highlight the factors that ail Nigeria at the systemic level. Semioticians engage in a search for deep structures underlying the surface features of phenomena. With Semiotic theory as framework, this paper takes seriously the social conditions that led to the \#EndSARS Protests, not neglecting the role of ideologies. The research has the potential to make useful contributions to both academic and socio-political cum economic knowledge for a meaningful national dialogue among contesting ethnic groups in Africa.
\end{abstract}

Keywords: Semiotics. Signifier. Signification. restructuring. \#EndSARS. 


\section{Introduction}

At independence in 1960, the country had three (later four) autonomous regions, each having full control of their resources and political affairs under the supervision of regional premiers. The details of what happened to upset this structure revolve around months of Nigerian civil war. However, the difficult-to-define structure and system being operated since the civil war has put the country on a retrogressive path. The 1999 Constitution has not helped matters by over centralising economic and political powers at the centre. This structure has led to uncontrollable corruption, prebendal-rent seeking, inequity, godfatherism, and so on.

A basic assumption of semiotics is that nothing is a sign until someone interprets it as a sign, and everything is a sign when so interpreted. SARS is an acronym for Special Anti-Robbery Squad. Going by the theories of various semioticians and their models of interpretation, the \#EndSARS takes a layered meaning, thus becoming a sign system that can have multiple interpretations and multiple meanings through both signification and Semiotization. SARS becomes a sign representing a different thing from what

the denotative meaning of the acronym represents, such that instead of SARS presenting a mental image of the police as security agents that evoke safety and expel fear, it rather evokes fear, terror, insecurity, brutality, extortion and in an extreme case, death. In place of patriotism and love, it arouses hateful mental feelings. If, as most semioticians agree, a sign is something which represents something else other than itself, it follows that nothing is a sign until it is interpreted as signifying something by someone. That is something representing another thing different from what is apparent; attempting to unlock a deeper meaning and bestow a deeper understanding of an object, a narrative, a phenomenon or an event, other than what the surface meaning denotes. The \#EndSARS signs and symbols have taken layered meanings, and thus become a sign system deserving of interpretation and study.

Lekki Tollgate also takes on semiotic characteristics as a sign which no longer represents a place for motorists to pay a token fee to pass through, but the mental image evoked is the place of slaughter/murder; a place where the security agencies of Nigeria opened fire with live ammunition on unarmed youths protesting peacefully, kneeling (as it were, praying), and singing the national anthem and waving the national flag. The Lekki Tollgate takes on a different meaning and 
begins to evoke an image of terror in the minds of people, especially the youths of Nigeria. The live-streaming of the Lekki Tollgate shooting on social media produced layers of significations, as the international community had their interpretation of the \#EndSARS protests. The hashtag further semiotized the \#EndSARS as it trended on all social media platforms, especially Twitter and Instagram. This study examines events leading up to the \#EndSARS saga as well as the various signs and symbols emanating from the protests. The main thesis of the study is that the protests represent symptoms of systemic issues which range from ideological differences of various ethnic nationalities to a constitutional and structural imbalance in the political and economic equation of Nigeria. The data for the study will be drawn from the signs and symbols stemming from the protests, which will then be subjected to semiotic interpretations.

\section{Semiotics framework and \#Endsar protest}

Semiotics is defined here as the art that studies signs and their meanings. This simple definition raises the question of what a sign is. A most basic definition of a sign is that given by Umberto Eco (1976, cited in Chandier, 2014) in which he asserts that a sign is anything that stands for something else other than itself. Semiotics deals with processes of making meaning and the ways by which various types of texts might be used to represent reality and tell stories. In other words, signs are representations having nothing inherently true in and of themselves, whether they are linguistic signs, iconic signs, index signs or symbolism signs. Rather, signs acquire meanings using cultural conventions and peer group interpretations.

From the initial works of Saussure and Peirce in which semiotics theory dealt with linguistics and scientific study of language, semiotics has since expanded to conceptualize the general study of signs. Saussure's model of semiotics divides a sign into two inseparable components the signifier and the signified, while the relationship between the two is signification. Saussure maintains that the linguistic sign does not unite a thing and a name but rather a concept and the sound, image or gesture (Saussure, 183, cited in Chandier, 2014). Saussure's dyadic model is represented

thus: Sign = Signifier + Signified.

Peirce, on his part, argues that all social practices can be seen as a sign (representamen) which stands for 
something (its object) to somebody (its signification and signified. While interpretant) in some respect or capacity Saussure's model emphasises the natural (its ground) (Peirce, 1931, cited in Yekini, language (that is words) as the sign Adegbite \& Omoteso, 2019). Peirce, system, Peirce's model emphasises the therefore, introduces what he refers to as sequence of events in the narrative or the triadic interactions of these terms, group of narratives as the sign system (as known as semiosis which refers to the cited in Yekini et al, 2019). Peirce's triadic process of signification that is distinct from the dyadic relationship of Saussure's model can be represented in a triangle thus:

Representamen (Signifier)

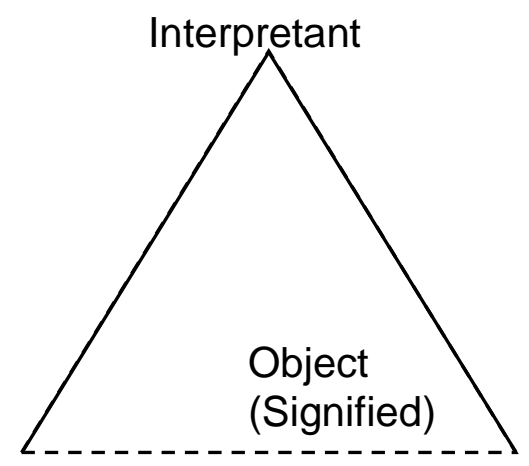

Figure 1: Peirce's Triadic Model (Source: Semiotic for Beginners, Chandier, 2014)

While both the dyadic model of Saussure be employed more extensively in this and the triadic model of Peirce are research as a means of circumventing the relevant in the analysis of the signs of the limitations of emphasis on linguistic and \#EndSARS protests, more modern verbal language by the two earlier models. semiotic traditions including those of Barthes, Greimas, Eco, and Chandier among others, which are extended arms of the Saussurean and Peircsean models will

The main thesis statement of this study is that beyond the brutalities of the Special Anti-Robbery Squad (SARS), the \#EndSARS protest is a marker of the many 
problems of Nigeria. The ethnic and theatre and film studies, religious colouration that caused phenomenological studies, hermeneutical discordant tunes between Northern and studies, etc. Goran Sonesson (2020) Southern protesters, reemphasise the regional dichotomies and serve as a signifier for a call to return to autonomous regionalism or confederationism. The brutality with which Nigerian combined security agencies crushed the protests speaks to the fact of the impracticability of Nigeria as presently constituted.

Semiotics is both a theory and a methodology that can be applied to a variety of 'texts', including novels, paintings, films and so on (Aiello, 2020). The term "text" is used broadly to refer to any semiotic object endowed with material or symbolic boundaries and structural anatomy, where various parts all have a function in relation to a "whole", and which can therefore be examined as a unit (Aiello, G. 2020). Semiotics aims to make hidden structures underlying cultural codes and dominant meanings of texts both discernible and comprehensible, thus making it an important tool for a methodical study and analysis of ideology in visual, non-verbal and phenomenological communications. In that sense, therefore, semiotics functions both theoretically and methodologically and has been adopted across disciplines such as art history, cultural studies, identifies about four methods in Semiotics: text analysis, system analysis, experiment, and text classification. Text analysis involves treating meaningful phenomenon taking place within a culture. An example can be the \#EndSARS, taken as the 'text' of a given system, being exhaustively reducible to a series of repeatable elements and the rules for their combination. So, the basic assumption of textual analysis is put more clearly by stating that behind all phenomena there is a categorical framework the instantiations of which are seen to recur all through a series characterised by a constellation of categories. The versatility of semiotics lends it easily as a resource across disciplines. This study will deploy multiple semiotic methodologies including social, cognitive, phenomenological, and Greimasian semiotic model of analysis. Embedded in the foregoing models are the semiotics of iconicity and visuality.

From a methodological standpoint, social semiotics combines descriptive, interpretative, and critical levels. Firstly, at a descriptive level, a social semiotic analysis focuses on making inventories of key visual resources in and across texts, thus outlining the basic semiotic 
repertoire of a given type of imagery or phenomena. Second, from an interpretative standpoint, this analytical approach focuses on situating visual resources and semiotic repertoire in their specific historical, cultural, or institutional contexts of production and use, considering how key meaning potentials are established through the selection and combination of particular visual resources. In addition, from a critical perspective, a social semiotic analysis links texts and contexts to understand the ideological import of imagery (Aillo, G. 2020).

Roland Barthes' focus on representation and connotation (1987), and Floch's emphasis on the perceptual and compositional characteristics of images (2000), are both key to the social semiotic understanding of visual analysis. In combining both ideological and formal concerns with a focus on cultural practices and social action, social semiotics offers an especially comprehensive framework for visual and critical analysis. Furthermore, social semiotics interrogates the ideological underpinnings and political implications of semiotic choices that become naturalized over time, and which are thus often taken for granted as the most sensible or natural ways of representing given type of knowledge and information. Social semiotics sees ideology as the premise for signification, not merely one of its layers. It highlights the fact that texts are never made by accident. It sees meaning-making or signification as a process deeply embedded in existing cultural norms and shaped by social structures. It shares similar foundations and goals with cultural studies as well as visual rhetoric, but its analytical focus is firmly on the text and how images work semiotically. As a methodology that is highly akin to critical discourse analysis, social semiotics is interested in the processes and products of discourse and their vital role in the production and transformation of the social practices that constitute the society in which we live (as cited in Aiello, G. 2020).

From the social semiotic perspective, signmaking is ultimately governed, though not determined, by authority, expertise, or simple conformity in a particular context. As a whole, this framework is well suited for interpretative and critical visual analysis in empirical observation of visual texts and offers a framework that is a fine-grained approach to visual analysis.

Cognitive semiotics integrates methods and theories developed in disciplines of cognitive science and the humanities to provide new insights into the realm of 
human signification and its manifestation in social and cultural practices (Zlatevi, 2012). However, considering the multiple meanings of the term "cognitive", a wide range of semiotic theories (from Saussure and Peirce to Eco and Hoffmeier) qualifies as cognitive semiotics which is considered a transdisciplinary study of meaning, and which could be related to ontological pluralism and methodological triangulation.

\section{Pictorial signifiers}

Pictorial semiotics differs from other studies in signification in that it does not just establish limits and altered focus for an old study, rather, it is a virgin field not cultivated a priori; that is if we define pictorial semiotics as the study of pictorial signs. The \#EndSARS protest produced pictorial signs and icons. And so, this study is also concerned with pictorial semiotics; concerned with pictures than iconicity. Also included is film semiotics or more appropriately, video clips semiotics as the \#EndSARS protest produced an unprecedented abundance of film verité on video clips showing unedited moments of action. They also produced snapshot moments of historical and semiotic importance. Because Semiotics is both a theory and a methodology, it represents and interprets as the process of meaningmaking unfolds, and meanings and realities are not just reflected or represented, they are also constructed.

\section{The Greimasian model of analysis}

The Greimasian narrative semiotics identifies the structural pattern in narrative and aims to clarify the necessary conditions producing values through which reality may be perceived (as cited in Yekini et al, 2014). This model looks beyond the sign itself into the system of signification to uncover the reality of the sign. The Greimasian narrative semiotic model is suitable for aspects of this study because the study is looking to uncover the deep meanings and hidden structures in the \#EndSARS protests from the various sign systems emanating from the movement.. The study considers \#EndSARS disclosures which are recorded social messages, narrated in the form of stories in the social media and official mainstream media reports. They consist of stories that could be rearranged in order to achieve a recuring structure that lends itself to semiotic analysis. The \#EndSARS protests triggered several signs whose meanings, as visual signs, semiotically differ from the meanings conveyed typically by visual means. To work out the distinction will require the employment of perceptual theory which, however, is outside the scope of this work. The present paper shall focus on theories 
within the realm of semiotics as already proposed in the foregoing sections dealing with various semiotic theories and methodologies.

\section{The \#EndSARS protests: An overview}

SARS is an acronym for Special AntiRobbery Squad, a wing of the Nigeria Police Force under the State Criminal Investigation and Intelligence Department (SCIID). SARS was founded about three decades ago as a criminal investigation and intelligence department to detain, investigate, and prosecute persons involved in criminal activities such as robbery and kidnapping. The squad was to function as an undercover agent for effective detection and prevention of crimes. It was not long after the establishment of SARS that accusations of human rights violations, extrajudicial killings, sexual harassment and brutalities began trailing the special squad. These rights violations were documented with videos trending on social media by individuals and human rights organisations such as Inter-Society and Human Rights Watch. It came to a point in 2017 when youths across Nigeria staged peaceful protests to draw attention to the brutalities and extortions perpetrated by members of SARS. That was when the End-SARS hashtag was first coined, and it trended briefly on social media. It is believed to have been first coined and used in 2017 by Segun Awosanya, who goes by the Twitter name of SEGA L'eveilleur @segalink.

Segun Awosanya, aka @seglink, had been fighting for the rights and protection of young people against police brutality (2019). But it was not until October 2020 that the, \#EndSARS, garnered traction and momentum as a well-organised movement that caught the attention of the Nigerian establishment, and almost brought economic activities to a halt, demanding an end to the brutality of the police against the young people of Nigeria. After experiencing a revitalisation in October 2020, following more cases of abuse and brutality, mass demonstrations broke out all over major cities of Nigeria. Social media platforms like Twitter, Facebook and Instagram became agog with issues of the \#EndSARS movement. Millions of Tweets had the End SARS hashtag. Solidarity protests and demonstrations erupted in other countries by Nigerians in Diaspora and other nonNigerian sympathisers. One significant feature of the movement was the demography; it involved the young people of Nigeria aged between 18 and 35 years of age. From demanding the end to police brutality, the demands of the movement expanded to include good governance and 
accountability by public officeholders. The triggers of the movement include killings, rape of young women in police custody, assaults, illegal abductions, profiling of young people as fraudsters or yahoo boys, harassment by the Special Anti-Robbery Squad officials and general lack of freedom of expression and movement. Social media campaign by the Nigerian Twitter community and other social media platforms lent impetus towards mobilising for the \#EndSARS protests.

SARS officers were alleged to profile young Nigerians, mostly males, based on fashion choices, tattoos and hairstyles. They were also known to mount illegal roadblocks, conduct unwarranted checks and searches, arrest and detain without trial, rape women, and extort young male Nigerians for driving exotic vehicles and using expensive laptops and iPhones. Stories and video pieces of evidence of how officers of SARS engaged in kidnapping, murder, theft, rape, torture, unlawful arrests, humiliation, unlawful detention, extrajudicial killings and extortion of Nigerian citizens saturated the social and traditional news media outlets. A large section of the victims of the abuses of SARS has been young male Nigerians and few female Nigerians.
In a well-coordinated move, the youths of Nigeria, for the first time since the return to democratic rule, made a bold attempt at forging a united front to fight police brutality; for the first time, a movement that was not ethnically or religiously coloured was engineered by the cream of Nigerian youths. However, the \#EndSARS movement became infiltrated, first, by hoodlums who turned it into a violent protest. Secondly, it was hijacked by elements believed to have been sponsored by the opposition, to discredit the ruling party; thereafter, it was brutally crushed by the Nigerian security forces, including the police and army who used AK 47 rifles and live ammunition to shoot at peaceful unarmed protesters. There were video clips showing men suspected to be government officials with black jeeps dropping armed hoodlums to infiltrate the ranks of the peaceful protesters and turn the protest violent. Such actions suggested religious and political motives. The brutality with which the protest was crushed inadvertently suspended any chance of Nigeria ever forging a united country whose citizens can be proudly patriotic Nigerians first before their ethnicity and religious affiliations. 
The End SARS hashtag and its layers of meaning

In his book, Mythologies (1987), Roland Barthes postulated myth as another layer of signification in semiotics. Whereas connotation is the ideological meaning that is attached to a specific sign, myth relates to ideological concepts that are evoked by a certain sign. This corresponds to people's worldview or a culture's way of thinking about something, a way of conceptualizing or understanding it. The key phrase relevant to our discourse here is, 'ideological concepts that are evoked by a certain sign.' That leads this discussion to examine the concepts evoked by the \#EndSARS protests by asking relevant questions in the overall discourse of the \#EndSARS saga: What ideological concepts does the \#EndSARS as both a text and a phenomenon evoke? Unmarked jeeps, which signify government vehicles, were seen conveying hoodlums armed with dangerous weapons to infiltrate the ranks of the peaceful protesters to disrupt the peaceful protests, thus causing it to degenerate into violence which led to the destruction of lives and property. What ideological concepts do such video footages evoke? How are such signs to be perceived and interpreted?

Nigerian youth who gathered at Lekki Tollgate, kneeling and waving the Nigerian flag were shot at with war grade bullets, leading to the death of scores of youths. What ideology does such gruesome sight evoke about Nigeria, the Nigerian Government, and the security forces?

The Nigerian flag, the symbol of the sovereignty, strength, and unity of the country, had its colours redesigned with the blood of wounded and dead youths. The white segment of the flag became

stained with blood, presenting a variegated design of Green-(white-withred patches)-Green. What ideological meaning or concept does the stained flag evoke?

The snapshot moments of the protests foreground several semiotic sign systems. For instance, the moment when the activist, Aisha Yesufu raised her right hand with a clenched fist, defying both the water cannons and live bullets that were fired at the protesters; that image stands as a sign with layered meaning which also evokes certain ideologies, calling for various interpretations. Her hijab-clad bodyframe stands tall as a sign that the people of Nigeria were standing in solidarity, irrespective of religion. Another moment of signification is when the youths of Nigeria decided not to run from the avalanche of bullets fired at them, but instead fell on their knees in solidarity, 
singing the national anthem and waving the Nigerian flag. This moment of national solidarity was broken by the very disturbing moment, a few minutes later, when the army opened fire, shooting live ammunition into the crowd of kneeling youths, shockingly, in total disregard to the national anthem, the national flag, and all known rules of military engagement, even in war times.

Greimas (1987) explains signification as when a reader can uncover the truth inherent in a narrative by analysing the actions of the narrator using logical, temporal and semantic criteria. Hence, Greimasian semioticians believe that the actions or motives of the subject in the narrative are more important than the words used in describing the action. On the other hand, Barthesian semioticians are more interested in the code by which the narrator and the reader are signified throughout the narrative itself, rather than the narrator's actions or motives, or the effect the action would have on the reader.

Following both the Greimasian and Barthesian semioticians schema of interpretation, one could take each of the semiotic resources triggered by the \#EndSARS protests and interpret them in different ways, assigning different levels of meaning and layers of signification to them. The \#EndSARS itself has become a phenomenon that has produced many semiotic resources. As Barthes (1987) argues that bourgeois norms are propagated through representation, this study avers that the Nigerian government propagates tyranny by the representation of fear and intimidation through all the arms of security agencies, not excluding state-sponsored thugs and military show of force. Moreover, the more these representations are propagated through repetitions and multiple signifiers, the more they are experienced as universal norms within the country. This process of normalisation of anomalies causes myth to be read as a factual and axiomatic system.

The \#EndSARS Protests is a sign system that represents various challenges and grudges that young Nigerians have against the Nigerian State. These can be grouped as follows:

Marginalisation against the young generation by the older generation. The youths appear to have been robbed of their present and future by a corrupt old and dying generation. More than denying the youths opportunities to take part in governance based on merit is the stereotyping of every youth, who has a means of livelihood on their own terms, as fraudsters or Yahoo Boys. It appears that to look good has become synonymous with 
scamming and robbery, making every healthy youth police suspect and victim of police brutality. Looking good becomes a signifier for youth to be profiled by the police, and possibly killed extrajudicially.

\section{Brutality and intimidation against young} people by the security agencies:

The Special Anti Robbery Squad (SARS) appear to have become robbers themselves, as they robbed and brutalised youths with impunity under the protective cover of their official uniform. Police brutality against young people in Nigeria can be interpreted in terms of the frustrations of the police themselves who are very poorly paid, leading to low selfesteem when confronted by a well-fed and good-looking youth, in a country where everybody should supposedly be hungry and looking beggarly. The only way they can beef up their self-worth and exert their authority appears to be through intimidation using their guns since the youths are constitutionally forbidden to carry arms. The gun becomes the mark of the bully and a signifier for the unlimited powers of life and death which SARS officers wield ruthlessly over defenceless youths. The expensive gadgets like iPhones and Apple laptops they see in possession of these young people become signifiers for fraud. In their thinking, no youth can acquire such gadgets legitimately without dabbling into fraudulent activities or crime. Beyond that, the police evaluate themselves and their salaries and feel pained that their annual income cannot buy some of the gadgets they see in possession of the young people, in a country where youth unemployment is at an all-time high. In effect, they bring sentiments and envy in the duty of fighting crime.

\section{Protest against Nigeria as a failed state:}

Developed economies of the world are driven by the private sector, and the private sector create jobs, thus creating wealth for both state and citizens. Unfortunately, it is difficult to define what system Nigeria operates; a government that forbids the private sector from unlocking the vast wealth creation resources available in abundance in all the regions, by confiscating all factors of production in the exclusive list of a most confusing constitution called the 1999 Constitution, thus reducing the whole country to a mono-economy state whose only income comes from the sale of crude oil, the proceeds of which is shared among the 36 states, such government cannot be said to be sincere about running a free economy. The management of this monoeconomy has been in the hands of mostly the same set of people for decades without any form of development in sight. 
Some of these people ruled as military heads of state and members of the Supreme Military Council (SMC) before Nigeria's return to democratic rule. General Mohammadu Buhari who took power through the barrell of the gun in December, 1983 and was ousted in August, 1985 is the current President of Nigeria. General Olusegun Obasanjo who transitioned Nigeria to civil rule in 1979 came back as civilian president in 1999 . These two, with their surviving cabinet members, readily come to mind when one makes claims of recycling of leadership in Nigeria by the older generation. It is not clear whether the leaders of Nigeria intended to run a welfare state, communism, socialism or capitalism. Whatever the system they intended to run, it is obvious that it has failed and young people whose future has been mortgaged to service the extravagant lifestyles of corrupt politicians have run out of patience. The \#EndSARS protest is a signifier of their impatience.

\section{Retrogression of the Nigerian State}

While some individuals can boast of being wealthier than Nigeria as a country, the country itself is in penury. It appears that politicians deliberately play politics with Nigeria for their self interests while impoverishing the country.
Poverty level soars as a result, so much so that Nigeria has won the medal of being the poverty capital of the world according to the World Poverty Clock (2020), and the third most dangerous place to live in the whole wide world (Bloom, 2019). Yet, when young people find the means to survive, either by travelling overseas to work or by engaging in internet multilevel marketing, they are profiled as fraudsters and brutalised by security agencies. In all of this, confirmed criminal gangs are left to roam free because the SARS who are supposed to track and arrest them are too busy chasing after harmless youths to extort money from them. It is indeed a country drifting towards anarchy; what Nnolim (2011) referred to as "rudderless and heading nowhere."

\section{Gender-based violence and rape}

The \#EndSARS Protest was a collective action of the youths devoid of ethnic and religious colouration until it was hijacked by hoodlums and turned violent with sectional narratives injected to justify the killing of youths from a particular section and a particular religion. The youths bonded together in defence of young women who, when abducted by SARS officers, are beaten and raped in custody. Sometimes, the offence of a young lady could range from not greeting a SARS officer properly, to wearing clothes 
disapproved of by the SARS officers. The Nigerian state appeared to have been dazed that the youths could muster the will and resources to stand up to the tyranny of the powers of the Nigerian establishment.

\section{The signs of the \#EndSARS protests and their interpretations}

The infiltration of the ranks of the \#EndSARS protesters by hoodlums aided by security agents in government official cars (Jeeps, which are in themselves sign vehicles) is a signification of the subtle involvement of the government in creating monsters they are not always able to control. It is also a marker, pointing to government as the enablers of SARS brutality against young people.

Anti \#EndSARS counter-protests sponsored and supported by Northern politicians across party divides points to the North-South dichotomy as distinct blocs whose ideologies appear to be antithetical to each other. The Bloodstained national flag represents a death nail that has been hammered into the coffin of the ailing country. Nigeria has finally been destroyed with the shedding of the blood of its citizens. The contradictory statements from the military and the government represent violations of the oath of serving and preserving the oneness of Nigeria; it, therefore, exposes the hypocrisy of "One Nigeria."

The shooting of young people who were kneeling, waving the national flag and singing the national anthem means that Nigerian leaders have no value and reverence for the symbols of Nigeria as a country. It sends a message that there is no country to be proud of. The livestreamed video of the Lekki Tollgate shooting by Obianuju (aka DJ Switch) showed a brave young woman, yearning for a country to be proud of and risking her life to call the attention of the international community to come and help. All snapshot moments of the protest and iconic images and photographs of solidarity (e.g. Aisha Yesufu clad in hijab with a raised clenched fist) are visual texts that will continue to be studied and interpreted as sign systems emanating from the \#EndSARS protests. Beyond the signs and symbols triggered by the protest is also the exposure of the unbelievable actions of the security agents against its citizens - taking the incidents at Obigbo and Lekki Tollgate as examples. Unarmed youth on peaceful protests, who were on their knees, waving the Nigerian flag and singing the national anthem were gunned down. Defenceless citizens were abducted from Obigbo and transferred to unknown 
torture camps in the North. Women amongst them were serially gang-raped, out of which two were reported to have died (InterSociety, 2021).

Solving the underlying issues of \# restructure Or \#burst

Successful nations across the globe are known to have evolved and developed organically, despite several attempts at building empires which resulted in waging needless wars. Many of the countries known today as developed economies and models of what great nations should be passed through a phase of trying to forge mega-sized empires which eventually collapsed, or became unions of mutually agreed and beneficial autonomous political units through new arrangements. The example of the United Kingdom readily comes to mind. Nigeria could learn from those countries. It has become common knowledge that the Nigeria of today, which can shoot unarmed peaceful protesters, is not the same Nigeria that the founding fathers (Obafemi Awolowo, Nnamdi Azikiwe and Abubakar Tafawa Balewa) bequeathed to Nigerians at independence. In recognition of the unique nature of Nigeria as a geographical expression comprising hundreds of ethnic nationalities with distinct cultures, the founding fathers in agreement with the colonial masters opted for a parliamentary system of government, where regions were allowed autonomy to own and tap their resources and use such resources to develop their regions at their pace. While that arrangement was far from being perfect, it was a system that would have allowed a natural solution of separating gradually and peaceably into sovereign ethnic nations living peacefully as good neighbours in a symbiotic relationship devoid of any form of parasitism. But since the yoking together of disparate ethnic nationalities by the British colonialists, and forcefully maintained under the slogan of "One Nigeria" by the political class who benefit from the corruption and decay that permeate the polity, Nigeria has been a rudderless society heading towards anarchy.

The amalgamation of the Northern and Southern protectorates by Lord Lugard for personal convenience and ease of administration needs to be revisited and reviewed if Nigeria is to survive. Prior to Lugard, the Southern and Northern protectorates were administered as separate units of a business concern. The reasons advanced for the amalgamation were economic - Britain saw the need to use the wealth of the South to administer the North to retain ownership of the vast geographical space known as Nigeria. It 
would also appear that it was in the interest of Britain to keep political power away from the South so that through the feudal North, Britain could continue to rule Nigeria by proxy, even after independence.

Nigeria, at the moment, is at the brink of violent collapse and disintegration under the weight of its internal contradictions. The first is the ideological contradictions. Whereas most ethnic nationalities in the South are republican and democratic by nature, the North is deeply feudal, and the people are content with the feudal ideology; an ideology akin to what Britain had before democracy swept across most of the world. It was the feudal worldview of Britain and much of the rest of Europe that led them into empire-building and conquest of Africa and the rest of the world. In pre-colonial Africa, ethnic nations evolved organically, and leadership was merited by acts of valour beneficial to the ethnic nations. This would explain why there were so many ethnic nations living side by side and doing business together cordially.

Most of the peoples of the Southern part of Nigeria claim common ancestry, or common migration history and have lived side by side for centuries in a symbiotic relationship, barring skirmishes of intertribal hostilities which never degenerated to wars of conquest to take over another's ancestral lands. The same might be said of the North, but it must be noted that the Fulani, current rulers of Nigeria, are not indigenous to Nigeria. They came as warlike jihadists led by Uthman dan Fodio, with the aim to "deep the Qur'an into the Atlantic ocean" and thus claim the vast area of Nigeria for the Fulani of the whole world. However, his mission was truncated by the British colonial powers who halted the Islamic advancement to the Atlantic Ocean. And from recent happenings, and statements by Fulani leaders, it does appear the quest to conquer and claim the whole of Nigeria as Fulani homeland has been rekindled, hence, the need for a national dialogue to restructure the country back to autonomous regions with defined boundaries and territories of each region under the protection of regional securities; failing which an outright disintegration of the country into several sovereign nations might become inevitable.

Shortly after the independence of Nigeria, the meddlesomeness of the central government in the affairs of other regions, especially the Western region, culminated in what has come down in Nigerian history as Operation Wetie. It was the same meddlesomeness of Abubakar Tafawa 
Balewa that motivated the middle cadre Nigerian army officers to plot a bloody coup that led to an ethnic motivated counter bloody coup that finally plunged the country into a needless genocidal war against Biafrans. Again, British interests fuelled the war. Whatever might be said of the war and its outcome, one thing remains clear, and that is that the factors which led to the coup and counter-coup are still rife today in a much more frightening dimension: the mindless bloodletting which led to the declaration of the Republic of Biafra has not abated more than sixty years after. And the war that was fought to force the East back into the cage of Nigeria has not ended; its style and strategy changed to a more subtle approach. So, in actuality, the war did not end, rather, the method and strategy changed.

The \#EndSARS Protests stand as a sign vehicle of signification in referent to a faulty foundation of Nigeria as a country of diverse ethnic nationalities operating a system of government which popular media have termed 'Unitary Feeding Bottle', on account of its unsustainable mono-economy, supervised by a political elite who appears to be totally oblivious of the ills of the system. The \#EndSARS Protests are the sign vehicles that carried the bottled-up grievances and pent-up emotional trauma of the victims of the brutalities against innocent citizens. It was a protest against the retrogression of Nigeria as a country that has resulted in lack of jobs and income-generating opportunities to drive self-employment. Put in another way, it represents judgment and condemnation of the 1999 Constitution in which all factors of production are confiscated by the government in the exclusive list, leaving nothing and no room for privately driven initiatives to thrive, and yet fails to provide basic amenities such as electricity, water and good roads. It was a protest against a system that appears intent on punishing hardwork while rewarding mediocrity; a system that rewards terrorists and bandits with foreign scholarships and choice government positions from one section, while jailing innocent hardworking young people from another section.

The \#EndSARS Protests were a reaction against everything that is wrong with Nigeria, from the quota system policy to the federal character clause designed to frustrate people from some sections of the country. The 1999 Constitution ensures that regions are not allowed to develop at their pace; they are compulsorily stagnated to ensure that the wealth from one section of the country is used for the benefit of another section, while the goose 
that lays the golden egg remains pauperized. A few individuals are made lords of the South against their ideological inclinations, thereby attempting a change in the philosophy of the indigenous communities. This is the reason traditional rulers (Igwes and Ezes) are installed against the will of the people and are deposed at will with impunity by political office holders. Traditional stools are desecrated at will, and those who should speak out fail in their main duties out of fear of falling out of favour. Political offices and traditional stools have been commercialised and governance turned into personal goldmines to the detriment of national cohesion and development.

The fish has rotted from the head and permeated the rest of the body; the water is poisoned from the source and flows down to all the pools that receive from the same source. Nothing can be done to heal the pools without first healing the source. This explains why security agencies would leave Boko Haram and kidnappers to instead brutalise young Nigerians, sometimes turning kidnappers and robbers themselves. Young people are made to pay ransom to the police and the army to free themselves. All a youth has to do to be criminalized and arrested by the SARS is to look good and well-fed; own a laptop and a smartphone. If you have tattoos or dreadlocks, you get an additional tag of a cultist. And as soon as they have forced you to empty your bank account, you are released: charges dropped without investigation. If you or your family is not able to pay, you are either extrajudicially killed, or left to rot in police cell with no records of your offence or even of your existence in their custody. Many have been tortured to death and their bodies disposed of secretly. Some have had their vital organs harvested and sold to a syndicate of organ buyers. Such bizarre stories are common. These ugly stories got to a point that the youths called for an end to the Special Anti-Robbery Squad (SARS), the special unit of the police that was seen to perpetrate the heinous acts. But the SARS unit is just the execution arm of a more deeply entrenched evil syndicate within the Nigerian government and those at the corridors of power.

\section{Summary and conclusion}

In this paper, Semiotic theory has been employed as a framework to explore the deeper meanings of the social conditions that led to the \#EndSARS Protests, not neglecting the role of ideology in the whole saga. Culturally, people depend on signs to make sense of the world around them. The art that explains to people how both languages and imagery combine to construct reality is called semiotics. 
Ferdinand De Saussure and Charles Sanders Peirce, the fathers of the two main traditions of semiotics, developed their theories independently of each other, but simultaneously in the 19th century. While De Saussure's semiotics focused on the relationship of the signifier to the signified, and with one sign to others, Sanders Peirce's semiotics focused on the relation between a sign and its object, or referent. De Saussure was of the view that linguistics signs were arbitrary, that a linguistic sign is the result of an arbitrary connection between a sign and its signified, or its material and the mental concept associated with it (as cited in Aiello, G, 2020). Saussure's idea of sign appears to have been limited to verbal language. His theory contributed to the development of a conceptualisation of meaning as dependent on historical, cultural and social factors. This has led to the adoption of a structural approach to signification in cultural theory and visual analysis. Sanders Peirce, on the other hand, identified three main types of signs characterized by three different modes of relationships to their objects, or referents namely an icon, an index sign, and a symbol. Symbols are connected to their objects by agreements, codes, rules, or habitual connections. Habitual connections, as with the \#EndSARS hashtag, was habitually connected with police brutality against youth in Nigeria. So, it became a symbol of protest and resistance against the highhandedness of the security forces of Nigeria, and their extrajudicial killings.

In conclusion, this paper posits that the \#EnSARS Protests by Nigerian youths represents symptoms of systemic issues in Nigeria. Those issues range from ideological and cultural differences of the various ethnic nationalities of Nigeria to the constitutional and structural imbalance in the political and economic landscape of Nigeria. Having put in perspective the implications of the overcentralisation of Nigeria and the concentration of both political and economic powers at the centre, the present author advocates for decentralisation (restructuring or unbundling) of the country into autonomous regions. The \#EndSARS hashtag, as a sign, not only represented youth protests against police brutality in Nigeria, it also evolved to become an instrument through which dissatisfaction was expressed by various groups who had axes to grind with the government of the day. This conclusion was arrived at by careful examination of the events that led to the \#EndSARS protests, as well as the 
various signs and symbols emanating from the \#EndSARS movement.

It has become obvious that no progress will be made for as long as Nigeria continues to operate the subsisting structure of governance. Therefore, a National Roundtable of honest dialogue is recommended to decide what to do with Nigeria. At the end of the Roundtable the international community should be invited to supervise a referendum/plebiscite of the major regions of Nigeria. The peoples of Nigeria (not the politicians or the ruling elite) need to be allowed to decide where they belong and who they would associate with. A redefined Nigeria, divided into smaller sovereign nations managing their own affairs and resources, might be the elixir for development of the entire geographical space called Nigeria. 


\section{References}

Aiello, G. (2020). "Visual semiotics: Key concepts and new directions". In Luc Pauwels and Dawn Mannay (Eds.), The SAGE Handbook of Visual Research Methods. London: SAGE.

Awosanya, S. (2019). Wikipedia, the free encyclopedia. Wikipedia.org. https://en.m.wikipedia.org

Barthes, R. (1987). Mythologies. New York: Hill \& Wang.

Bloom, L. B. (2019). Ranked: The 20 Most Dangerous Places to Live. Forbes. https://www.forbes.com/sites/laurabegleybloom/2019/09/05/20-most-dangerousplaces-to-live-2019/?sh=23da8cc37022

Cambre, C. (2012). "The efficacy of the virtual: from Che as Sign to Che as agent". In Paul Boussc and Tom Wysocki (Eds). The public journal of semiotics. Vol. IV, October 2012, No.1

Chandler, D. (2014). Semiotics for Beginners. http://visual-meaning.co.uk/daniel/documents.

Eco, U. (1976). A Theory of Semiotics. Bloomington, IN: Indiana University Press

Floch, Jean-Marie (2000). Visual Identities. London: Continuum.

Greimas, A. J. (1987). On meaning selected writing in semiotic theory. University of Minnesota.

InterSociety. (2021). Nigerian Islamic Jihadists massacred 1, 470 Christians in first four months of 2021 and abducted over 2,200. InterSociety: Rule of Law. https://intersocietyng.org/nigerian-islamic-jihadists-massacred-1-370-christians-in-first-four-monthsof-2021-and-abducted-over-2500/

Nnolim, C. (2011). Chinua Achebe: A re-assessment. Tydskrif Vir Letterkunde, 48(1). https://doi.org/10.4314/tvl.v48i1.63819

Sonesson, G. (1993). "Pictorial Semiotics, Gestalt Psychology, and the Ecology of Perception." Review of Saint-Martin, Fernande, La theorie de la.

Thomas, R. (2012). "If we are too small to see or you have forgotten: A postcolonial response to modern representations of the San". In Alexander McCall Smith's No Ladies 
detective agency series. www.academa.edu.

World Povert Clock. (2020). World Poverty Clock. Worldpoverty.io. https://www.worldpoverty.io/headline

Yekini, K. C., Omoteso, K., \& Adegbite, E. (2019). CSR communication research: A theoreticalcum-methodological perspective from semiotics. Business \& Society, 6044), 000765031984362. https://doi.org/10.1177/0007650319843623

Zlatev, J. (2012). Cognitive Semiotics: An emerging field for the transdisciplinary study of meaning. In The Public Journal of Semiotics. Vol. IV No.1 